Karol BUJNOWSKI

WSD Elk

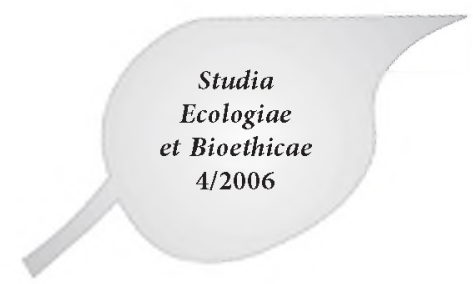

\title{
Pytanie o sens życia
}

\section{Wstęp}

Temat sensu życia nigdy nie był tematem obcym człowiekowi. Ludzie od najdawniejszych czasów zadawali sobie pytanie o sens swego istnienia oraz poszukiwali czynników, które mogłyby go nadać ich egzystencji. W dzisiejszym świecie coraz częściej słyszy się pytanie o sens życia. Pomimo wielkich odkryć i osiągnięć technicznych, pytanie to jest ciągle aktualne.

\section{Ogólna charakterystyka problematyki sensu życia}

Sens życia byl na przestrzeni historii rozumiany w różny sposób. Również i współcześnie istnieje wiele koncepcji odmiennie ujmujących to zagadnienie. Niezależnie jednak od różnorodności tych koncepcji, o sensie życia można mówić w sposób ogólny, wspólny wszystkim próbom ustosunkowania się do tego problemu.

\subsection{Próba zdefiniowania zagadnienia sensu życia}

Samo słowo „sens” pochodzi od łac. „sensus”, co oznacza przede wszystkim zmysł, poznanie zmysłowe lub uczucie. Innym znaczeniem tego terminu jest sposób myślenia, pogląd, pewien sąd, znaczenie czy też smak lub gust ${ }^{1}$.

Według J. Tischnera termin „sens" należy do pojęć pierwotnie niedefiniowalnych, oznacza to, dzięki czemu coś jest zrozumiałe ${ }^{2}$.

T. Ślipko zwrócił uwagę na ewolucję, którą przeszedł łaciński termin „sensus” w rozwoju języka filozoficznego. Mimo swojej wieloznaczności termin ten nie był wiązany z pojęciem życia ludzkiego. W językach nowożytnych znaczenie słowa "sens" uległo dalszej ewolucji znaczeniowej i z czasem zaczęło oznaczać cel życia

Por. W. STróżEwski, Istnienie i sens, Kraków 1994, s. 205.

2 Por. J. Tischner, Sens, [w:] Katolicyzm A-Z (red. Z. Pawlak), Poznań 1982, s. 342-343. 
człowieka. Oba te terminy, sens i cel, bardzo często występują zamiennie w odniesieniu do życia ludzkiego ${ }^{3}$.

Zagadnienie sensu jest bardzo złożone i z tego powodu analizowane jest ono z wielu aspektów. W. Stróżewski podał propozycję rozpatrywania problematyki sensu na sześciu płaszczyznach:

a) semantycznej - o sensie można mówić na poziomie najprostszej jednostki semantycznej, czyli nazwy, ponieważ nazwa sama w sobie jest elementem sensownym, a zarazem sensotwórczym;

b) fenomenologicznej - fenomenologia wychodzi w swoich założeniach od tego, co jest „dane" dla podmiotu poznającego. Poznanie zmysłowe porządkuje te dane, nadając im pewien sens, co następnie służy do tworzenia innych „tworów sensownych". Wszystko to dokonuje się na płaszczyźnie intelektualnej;

c) ontologicznej - warunkami konstytuwnymi sensu są ład i racjonalność, w pojęciu sensu ontologicznego zawiera się rzeczywistość bytu, a także świadome odniesienie się człowieka do tego bytu;

d) ontycznej - racjonalność rzeczywistości ontycznej jest niezależna od człowieka i w taki właśnie sposób ta rzeczywistość jest przez człowieka postrzegana, sens ontyczny nadają światu kierunki teistyczno - kreacjonistyczne;

e) aksjologicznej - wartości występują jako czynnik sensotwórczy;

f) metafizycznej - stawia się tu pytanie o sens istnienia ${ }^{4}$.

Podobnie jak pojęcie samego sensu, tak i pojęcie sensu życia, jest wieloznaczne. $Z$ tego powodu wielu autorów wprowadza tu pewne rozróżnienia. T. Czeżowski wyróżnił cztery znaczenia pojęcia sensu życia :

a) wewnętrzno-jednostkowy;

b) zewnętrzno-społeczny;

c) filozoficzny;

d) pragmatyczny.

S. Kowalczyk zaproponował poszerzenie rozróżnienia pojęcia sensu życia o nowe elementy. Według niego można wyróżnić następujące znaczenia idei sensu życia:

a) kosmologiczne i antropologiczne;

b) historyczne i doktrynalne;

c) ontologiczne i aksjologiczne;

d) jednostkowe i społeczne;

e) naturalne i nadprzyrodzone.

3 Por. T. ŚLIPKo, Sens życia - sens dziejów. Refleksje ze stanowiska filozofii i etyki chrześctjańskiej, Studia Filozoficzne, $1981 \mathrm{nr} 4$ (185), s. 109-116.

4 Por. W. StróżewsKi, dz. cyt., s. 425-435.

5 Por. T. Czeżowski, Jak rozumieć sens życia?, [w:] Odczyty filozoficzne, Toruń 1958, s. 233, za: S. KowalCZyK, Podstawy światopoglądu chrześctiańskiego, dz. cyt., s. 426. 
Ad. a.) S. Kowalczyk rozróżnia przede wszystkim kosmologiczne i antropologiczne znaczenie sensu życia. Człowiek zawiera w sobie trzy „formy” życia: biologiczno-wegetatywną, zmysłową i duchową. $Z$ tego względu zajmując się sensem ludzkiej natury trzeba uwzględnić te wszystkie płaszczyzny. Pojęcie sensu życia zawiera w sobie w głównej mierze profil antropologiczny, ponieważ odnosi się do człowieka, który jest zdolny do samodecydowania i samokierowania. Dzięki rozumowi i wolnej woli człowiek jest zdolny do poszukiwania sensu życia. Z racji, iż jest on częścią kosmosu, jego egzystencja jest włączona w sens całego świata. Gdyby cała struktura wszechświata pozbawiona była sensu, nie można byłoby mówić również o sensie ludzkiego istnienia.

Ad. b) Historia poglądów na sens ludzkiego życia jest związana z historią koncepcji bytu, człowieka, życia itp. W zależności od przyjętej koncepcji człowieka czy życia, kształtował się również pogląd na sens życia.

Ad. c) W rozróżnieniu ontologicznym i aksjologicznym chodzi o ujęcie sensu istnienia człowieka $w$ aspekcie statycznym, mówiącym o tym, kim jest człowiek, oraz $w$ aspekcie dynamicznym, opisującym kim człowiek się staje. Człowiek powołany jest do doskonalenia się poprzez aktualizację ogólnoludzkich wartości $\mathrm{i}$ to jest aksjologicznym znaczeniem sensu życia.

Ad. d) Mówiąc o sensie ludzkiego życia, zwykle ma się na uwadze sens w znaczeniu jednostkowym. Cierpienie, śmierć, przyjaźń czy miłość należą do problemów, które każdy człowiek musi w swoim życiu sam rozwiązać. Człowiek jest jednak zarazem istotą społeczną i dlatego własne plany i działania musi włączyć w pewne formy społeczności, takie jak rodzina czy państwo. Za sens ludzkiego życia można więc także uznać służenie innym.

Ad. e) Ostatnim rozróżnieniem jest rozróżnienie na sens naturalny i nadprzyrodzony. Z reguły każdy człowiek, obok celów „przyziemnych”, posiada jakiś cel najwyższy. Może nim być Bóg, sztuka, kariera czy walka o sprawiedliwość społeczną. Ten najwyższy, nadrzędny cel nadaje ludzkiemu życiu wartość i sens ${ }^{6}$.

Mówiąc o zagadnieniu sensu życia, zwykle ma się na myśli właśnie ten „sens najwyższy". Sens życia pojmowany jest więc ogólnie jako pewna idea, wyrażająca przeświadczenie o istnieniu pozytywnej odpowiedzi na podstawowe pytania człowieka dotyczące jego egzystencji. Pogląd przeciwny temu twierdzeniu mówi o absurdalności i bezsensowności ludzkiego życia7.

M. Gogacz przez sens życia rozumie osiąganie przez człowieka celów, które wybrał i uznał za najważniejsze i najdonioślejsze w swoim życiu. Człowiek podporządkowuje całe swoje działanie osiągnięciu tych celów, uznając je za najwyższe wartości, w których spełnia się jego człowieczeństwo. Dlatego sens życia

\footnotetext{
Por. S. Kowalczyk, Podstawy światopoglądu chrześcijańskiego, dz. cyt., s. 426-428.

7 Por. T. Sikorski, Sens życia, [w:] Slownik Teologiczny (red. A. Zuberbier), t. II, Katowice 1989, s. 238.
} 
przenika całą psychikę człowieka, jego myślenie i decyzje. Sens życia nie jest więc zrealizowaniem celów czy spełnieniem człowieczeństwa, ale dążeniem do nich i jawi się jako relacja wiążąca człowieka z jego celami ${ }^{8}$.

Według A. Adlera pytanie o sens życia ma tylko wtedy wartość, jeśli rozpatrywane jest $\mathrm{z}$ aspektu wzajemnej zależności „człowiek - kosmos”. Kosmos jawi się tutaj jako „ojciec" wszystkiego, co żyje i posiada moc kształtującą, życie natomiast jest ciągłym rozwojem. Żyć, według Adlera, znaczy rozwijać się i właśnie w owym rozwoju upatruje on źródło sensu istnienia ${ }^{9}$.

Adler wysuwa pogląd, że wszystkie zagadnienia życia, a więc i jego sensu, należy rozpatrywać $w$ aspekcie trzech wielkich problemów: życia w społeczeństwie, pracy i miłości. Nie są to kwestie przypadkowe, ale nieustannie stojące przed każdym człowiekiem, przed którymi nie można się uchylić. Stosunek do tych trzech zagadnień ma wpływ na kształtowanie własnego stylu życia. Problemy te wynikają z faktu społecznego charakteru natury człowieka, z troski o zabezpieczenie utrzymania, a także z potrzeby przekazywania życia. Do rozwiązania trzech powyższych kwestii zmierzają przejawy życia człowieka, takie jak: przyjaźń, koleżeństwo, troska o dobro państwa, przygotowanie do pracy, odniesienie do drugiego człowieka, a w szczególności do człowieka płci przeciwnej ${ }^{10}$.

Samo istnienie człowieka wśród innych bytów stworzonych można rozpatrywać zarówno w porządku świata materialnego jak i duchowego. W pierwszym przypadku człowiek jawi się jako byt „zanurzony” w czasie i przestrzeni, natomiast w drugim jako byt myślący, posiadający wolną wolę. Egzystencja ludzka polega więc na „uobecnianiu” człowieka jako bytu cielesno-duchowego ${ }^{11}$.

I. M. Bocheński podejmując pytanie czym jest sens życia, stwierdza, że jest to pytanie, na które znalezienie odpowiedzi jest nadzwyczaj trudne. Według niego przy rozpatrywaniu tego problemu nie można posługiwać się ogólnikami typu „każdy człowiek", ponieważ sprawa sensu życia jest w najwyższym stopniu sprawą indywidualną i prywatną. Kiedy danemu

człowiekowi jego życie jawi się jako bezsensowne, to jest sprawą obojętną, czy to życie ma jakiś sens dla pewnej idei, społeczeństwa czy drugiego człowieka ${ }^{12}$.

8 Por. M. Gogacz, Sens zycia i wspólnota, Studia Filozoficzne, 1981 nr 4 (185), s. 109-114.

9 Por. A. Adler, Sens życia, Warszawa 1986, s. 243. Na temat rozwoju w zagadnieniu sensu życia pisze również K. Dąbrowski, Studia Filozoficzne, 1981 nr 4 (185), s.99-108.

10 Por. A. Adler, Sens życia, dz. cyt., s. 54-56.

11 Por. A. WoźNicki. W poszukiwaniu sensu egzystencji ludzkiej, Zeszyty Naukowe KUL, 21 (1978) nr $1(81)$, s. 30 .

12 Por. I. M. Bocheński, O sensie życia, Znak, 34 (1982) nr 3, s. 90-102. 
W strukturze sensu życia można wyróżnić następujące komponenty:

a) intelektualny;

b) emocjonalno-uczuciowy;

c) wolitywno-dążeniowy;

d) egzystencjalno-dążeniowy.

Komponent intelektualny jest związany z poznaniem natury życia człowieka, jego otoczenia i osobistych celów. Podkreślona jest tu zdolność jednostki do poznania swojej natury. Komponent emocjonalno-uczuciowy uwydatnia zdolność człowieka do reagowania na wartości i świadomego przeżywania swoich sukcesów i niepowodzeń. Składnik wolitywno-dążeniowy jest związany ze zdolnością człowieka do dokonywania wyborów i przyjmowania określonej postawy wobec zachodzących zjawisk. Natomiast komponent egzystencjalno-dążeniowy jest rozumiany dwojako: jako przyczyna zaistnienia poczucia sensu życia oraz jako wynik istnienia tego sensu. Takie rozumowanie obejmuje wybór konkretnego programu życia, a następnie konsekwentne jego realizowanie ${ }^{13}$.

Jak wynika z powyższych rozważań, zagadnienie sensu życia jest zagadnieniem bardzo szerokim. Można je badać i analizować z wielu aspektów i na różnych płaszczyznach.

\section{2. Sens życia jako psychologiczna potrzeba czlowieka}

Każda istota żywa, a więc także i człowiek, posiada wiele potrzeb. Im bardziej złożona jest struktura danego organizmu, tym bardziej rozbudowane są jego potrzeby. Szczególnie różnorodne są potrzeby ludzkie, ponieważ obok potrzeb biologicznych, wspólnych ludziom i zwierzętom, występują również potrzeby charakterystyczne wyłącznie człowiekowi, będące wynikiem jego cielesno-duchowej natury.

Najogólniej potrzeby ludzkie można podzielić na naturalne, inaczej organiczne lub biologiczne, oraz na potrzeby wyższe. Do potrzeb naturalnych zalicza się między innymi potrzeby pokarmowe i płciowe, a do wyższych - potrzeby poznawcze, estetyczne, moralne i duchowe ${ }^{14}$.

Potrzeby należą do czynników aktywizujących organizm. Wynikają one z braku czegoś, co sprawia, że organizm nie może normalnie funkcjonować ${ }^{15}$. Potrzeba jest czynnikiem ukierunkowującym działanie człowieka i należy ją odróżnić od popędu, który „popycha do działania” ${ }^{16}$.

13 Por. K. Popielski, „Sens” i „wartość życia jako kategorie antropologiczno - psychologiczne, w: Czlowiek - pytanie otwarte (red. K. Popielski), Lublin 1987, s.135.

14 Por. L. Woeoszynowa, Psychologia ogólna i rozwojowa, Warszawa 1965, s. 52-54.

15 Por. A. SowińsKa, Wprowadzenie do psychologii, Katowice 1996, s. 33.

${ }_{16}$ Por. H. Krzysteczko, Osobowość, [w:] Psychologia dla teologów (red. J. Makselon), Kraków 1995, s. 179. 
Potrzeby wyższe, do których zalicza się także potrzebę sensu życia, charakterystyczne są tylko dla rodzaju ludzkiego. Zaspokojenie potrzeb wyższych prowadzi do uczucia szczęścia, większej pogody ducha i bogatszego życia wewnętrznego ${ }^{17}$. A. Maslow opracował pewną hierarchię potrzeb, jako motywów działania człowieka. Potrzeby te ustawia w następującym porządku:

a) potrzeby fizjologiczne;

b) potrzeba bezpieczeństwa;

c) potrzeby przynależności i miłości;

d) potrzeba szacunku;

e) potrzeby wiedzy i rozumienia;

f) potrzeby estetyczne.

Pojawianie się coraz wyższych potrzeb uwarunkowane jest, według Maslowa, uprzednim zaspokojeniem potrzeb niższego rzędu ${ }^{18}$.

Wśród wielu rodzajów potrzeb najbardziej charakterystycznymi dla człowieka są potrzeby związane z osobowym wymiarem jego egzystencji. Potrzeby te najpełniej są wyrażane w szukaniu sensu na drodze realizowania i dążenia do pewnych wartości. Potrzeba sensu życia jest specyficznie ludzką potrzebą i często nazywana jest „potrzebą potrzeb” ${ }^{19}$. Pomimo wielu doświadczeń ze zwierzętami, zadne z tych stworzeń nie postawiło nigdy pytania o sens. Uczynił to tylko człowiek, który postawił pytanie nie tylko o sens własnej egzystencji, ale także o sens świata i całego kosmosu. Poczucie sensu życia nie jest zależne od osobowości danej jednostki, jej wykształcenia czy pochodzenia społecznego. Poczucia sensu doświadcza każdy człowiek, różne są tylko poziomy intensywności oraz sposoby ujawniania tego poczucia ${ }^{20}$.

Bez zaspokojenia potrzeby sensu życia człowiek nie potrafi normalnie żyć ani działać. Każdy człowiek, bardziej lub mniej świadomie, wytwarza sobie jakąś koncepcję sensu życia, według której rozwiązuje napotykane w codziennym życiu problemy. Człowiek musi znaleźć uzasadnienie tego, co robi, ponieważ w przeciwnym wypadku wszystko stałoby się dla niego bezsensowne ${ }^{21}$.

Potrzeba sensu życia wynika z samej istoty człowieczeństwa oraz z ogólnej sytuacji egzystencjalnej; między innymi z faktu istnienia człowieka w czasie, z którym związane jest zjawisko przemijania. Potrzeba sensu życia nabiera szczególnego charakteru i natężenia $w$ „przełomowych" momentach życia ludzkiego, kiedy człowiek musi stanąć wobec trudnych wyborów czy doświadczeń życiowych ${ }^{22}$.

17 Por. A. Maslow, Motywacja i osobowość, Warszawa 1990, s. 151-152.

18 Tamże, s. 72-92.

19 Por. K. Popielski, „Sens” i „wartość” życia jako kategorie antropologiczno - psychchologiczne, dz. cyt., s. 130.

20 Tamże, s. 133-134.

${ }^{21}$ Por. J. Mariański, W poszukiwaniu sensu życia, dz. cyt., s. 19-20.

22 Por. J. Kuczyóski, Sens życia, Warszawa 1981, s. 33. 
Wielkość i doniosłość potrzeby sensu życia najbardziej uwidacznia się w sytuacjach, gdy człowiek przestaje dostrzegać sens swego istnienia i doświadcza bezsensu całej swojej egzystencji.

V. E. Frankl wprowadził do psychologii pojęcie logoterapii, jako pomocy w uświadamianiu wartości i sensu życia osobom, które ten sens zagubiły ${ }^{23}$. Człowiek najczęściej stawia sobie pytanie o sens życia, kiedy doświadcza cierpienia. Wynika to z ludzkiej natury. Człowiek cierpiący zaczyna szukać wyjaśnienia swego stanu, szuka wyższych, duchowych wartości, które potrafilyby ten stan wythumaczyc ${ }^{24}$.

Według K. Dąbrowskiego do postawienia pytania o sens życia dochodzi dopiero na poziomie głębszego rozwoju świadomości oraz

samoświadomości, na poziomie silnych związków uczuciowych, rozwoju hierarchii wartości i ideału osobowości. Aby odczuć potrzebę sensu życia, trzeba odczuć najpierw niepowtarzalną miłość i przywiązanie do najbliższych, zetknąć się ze śmiercią bliskich i nie być obojętnym wobec niszczenia wartości, w które się wierzyło. Wtedy zagadnienie sensu życia stanie przed człowiekiem z całą wyrazistością. Pytanie o problem sensu życia, śmierci, przyjaźni i miłości, dobra i zła, wartości jest pytaniem bardzo ważnym, a nawet nadrzędnym. Bez ich rozwiązania życie traci sens ${ }^{25}$.

Potrzeba sensu życia należy więc do priorytetowych potrzeb każdego człowieka. Człowiek może w pełni realizować się ,jako człowiek”, aktualizować swoją potencjalność i realizować swoją istotę jako osoba ludzka tylko wtedy, jeżeli posiada sens życia ${ }^{26}$.

Jak już zostało wspomniane, człowiek jest jedyną znaną istotą poszukującą sensu swego istnienia. Potrzeba sensu jest egzystencjalną potrzebą człowieka, ponieważ domaga się on, aby jego życie miało jakiś cel, pragnie zatem życia sensownego ${ }^{27}$. Doświadczenie sensu życia jest więc nieodłącznie związane $\mathrm{z}$ losem człowieka. Twórcy wielkich systemów psychologicznych zajmowali różne stanowiska w stosunku do tego faktu. Freud, przykładowo, mówił o potrzebie

23 Por. V. E. Frankl, Homo Patiens, Warszawa 1984, s. 19.

24 Tamże, s. 82.: „Nie jest bowiem prawdą, że czlowiekowi zależy na jedynie cielesnej wegetacji. Tym, o co czlowiekowi chodzi ostatecznie, jest istnienie duchowe. Czlowiek nie chce istnieć za wszelką cenę, ale to, czego naprawdę chce, to: żyć z sensem. Dla egzystencji miarodajne i decydujące nie jest jej trwanie, ale pełnia jej sensu. Wszak krótkie życie może być pełne sensu; a długie może być sensu pozbawione. Można nawet i tak powiedzieć: gdyby nie było śmierci, a życie trwało bez końca, już dlatego tylko byłoby pozbawione sensu. Człowiek mógłby wtedy wszystko, każdą sprawę od siebie odsuwać, co miałby zrobić dzisiaj, mógłby uczynić jutro i pojutrze. Nie byłoby żadnych zobowiązań i żadnej odpowiedzialności za wykorzystywanie chwili dla urzeczywistniania wartości i wypełniania bytu ludzkiego sensem."

25 Por. K. DĄBRowsKi, W poszukiwaniu zdrowia psychicznego, Warszawa 1996, s. 160-161.

26 Por. V.E. FrankL, Homo Patiens, dz. cyt., s. 64.

27 Por. S. Kowalczyk, Podstawy światopoglądu chrześcijańskiego, dz. cyt., s. 428-429. 
sensu życia jako o chorobie, a więc jako o czymś patologicznym. Według Junga człowiek rzeczywiście reaguje chorobą $\mathrm{w}$ związku $\mathrm{z}$ problemem sensu życia, ale nie z powodu jego potrzeby lecz braku. Inny z wielkich psychologów, Frankl, zaakcentował znaczenie sensu dla prawidłowego życia w wymiarze osobowym, a także dla zdrowia człowieka.

Zjawisko utraty poczucia sensu życia zostało stwierdzone klinicznie i najczęściej łączy się je z brakiem wartości lub niewłaściwego ich rozumienia, co ma kluczowe znaczenie dla egzystencji człowieka. Należy więc stwarzać warunki, w których dynamizm sensu życia i wartości mógłby się realizować. Dzięki temu człowiek będzie mógł funkcjonować prawidłowo, a nie patologicznie ${ }^{28}$.

\section{Fenomen religii a sens życia}

Istnienie religii jest niezaprzeczalnym faktem zarówno w skali historycznej jak i geograficznej. W obecnych czasach nie stawia się już pytań dotyczących istnienia religii, poniewaź jest ono czymś oczywistym. Powstaje jednak pytanie: po co jest religia i jakie ona ma znaczenie dla człowiek ${ }^{29}$.

Historia ludzkości dostarcza wielu dowodów na to, że religia jest nieodłącznym zjawiskiem życia ludzkiego. Gdziekolwiek pojawił się człowiek, wszędzie tam rozwijał jakąś formę aktywności religijnej. Pytanie o istotę religii dotyka najistotniejszych problemów człowieka, to znaczy sensu i perspektyw jego życia ${ }^{30}$.

Obecny wiek znalazł odpowiedzi na naukowe pytania, które stawiano w przeszłości. Nagromadzono znaczną wiedzę na temat człowieka i wszechświata, da się również zauważyć wielki postęp techniczny. Pomimo tych niewątpliwych osiągnięć, dla współczesnego człowieka nadal aktualne pozostaje „odwieczne” pytanie o sens jego istnienia ${ }^{31}$.

Z pomocą przychodzi człowiekowi religia, która nie jest jedyną drogą do nadawania sensu życiu, ale można zaryzykować stwierdzenie, że właśnie w religii można sens życia najszybciej odnaleźćc ${ }^{32}$.

28 Por. K. Popielski, dz. cyt., s. 136-137.

29 Por. M. Rusecki, Istota i geneza religii, Warszawa 1989, s. 84.

30 Por. Z. J. Zdybicka, Religia i religioznawstwo, Lublin 1988, s. 15; D. Olszewski, Z zagadnień religioznawstwa, Łódź 1988, s. 29-34.

31 Tamże, s. 35-36.

32 Zob. Deklaracja o stosunku Kościoła do religii niechrześcijańskich „Nostra Aetate”, [w:] Sobór Watykański II, Poznań 1967, s. 334-338.: „Ludzie oczekują od różnych religii odpowiedzi na głębokie tajemnice ludzkiej egzystencji, które jak niegdyś, tak i teraz do głębi poruszają ludzkie serca: czym jest czlowiek, jaki jest sens i cel naszego życia, co jest dobrem, a co grzechem, jakie jest źródło i jaki cel cierpienia, na jakiej drodze można osiągnąć prawdziwą szczęśliwość, czym jest śmierć, sąd i wymiar sprawiedliwości po śmierci, czym wreszcie jest owa ostateczna i niewysłowiona tajemnica, ogarniająca nasz byt, z której bierzemy początek i ku której dążymy." 
W ujęciu przedmiotowym religia oznacza zespół prawd i obrzędów, przez które człowiek zdąża do ostatecznego celu, którym jest Bóg. Natomiast w sensie podmiotowym przez religię rozumie się świadomość zależności od Boga jako Bytu nadnaturalnego $0^{33}$.

Człowiek jako osoba współtworzy więc religię, jest jednym z jej biegunów. Religia jawi się jako międzyosobowe zdarzenie w wymiarze indywidualnym i społecznym. Dokonuje się w niej tajemnicza komunikacja pomiędzy osobą ludzką a Osobą Bożą. Kontakt z Bogiem otwiera przed człowiekiem nowy horyzont istnienia i zycia nadprzyrodzonego, nadaje człowiekowi kierunek istnienia i dążeń, określa cel życia, który staje się sensem osobowej egzystencji jednostki ludzkiej.

Człowiek jako istota społeczna wyraża swój związek z Bogiem również w sposób wspólnotowy. Społeczne przeżywanie więzi z Bogiem stwarza nowe relacje interpersonalne, buduje religijny byt społeczny, określa jego możliwości i warunki rozwoju, wyznacza cel ostateczny wszelkich dążeń ludzkości, działań i procesów historycznych. Tym samym nadaje im sens, ukazując spełnienie się bytu społecznego tworzonego i budowanego przez religię.

Przeżywana przez osobę ludzka więź z Bogiem, zarówno w wymiarze indywidualnym jak i wspólnotowym, nie sprowadza się jedynie do sfery wewnętrznej człowieka. Religia inspiruje do działania i rozwoju osobowego, co przejawia się $\mathrm{w}$ tworzeniu wartości osobowych o charakterze religijnym i w przemianie świata. W tym znaczeniu religia jest wielką wartością, w której człowiek potrafi odnaleźć sens swojego życia poprzez współuczestniczenie w działalności samego Boga ${ }^{34}$.

Ukazywanie sensu życia oraz pomoc w jego poszukiwaniu należy do ważnych funkcji religii. Dzięki niej człowiek może przeżywać swoje życie, swoje dążenia i cele, radości i cierpienia w aspekcie głębszego sensu. Religia dostarcza wartości, norm jak i wyjaśnień, co do znaczenia całej ludzkiej egzystencji. Religia często potrafi dać najpełniejsze i najgłębsze odpowiedzi na pytanie o sens życia ludzkiego i całego świata ${ }^{35}$.

Człowiek będąc istotą rozumną, zdolną do dokonywania świadomych wyborów i do działania, dąży do zdobycia jak największej ilości informacji dotyczących różnych dziedzin życia, aby mieć pewną orientację w całej otaczającej go rzeczywistości. Wiedzę tę człowiek zdobywa przez całe swoje życie. Owa zdolność poznania nie tylko najbliższego środowiska, ale całej rzeczywistości, wyróżnia go od innych istot żywych. Wiedza ta jest niezbędna człowiekowi, bo dzięki niej może sobie uświadomić kim jest, jaką zajmuje pozycję w otaczającym

33 Por. L. KaCZMAREK, Istota i pochodzenie religii, Wąbrzeźno 1958, s. 63-64.

34 Por. M. Rusecki, Istota i geneza religii, dz. cyt., s. 144-146.

35 Por. J. Mariański, W poszukiwaniu sensu życia, dz. cyt., s. 60. 
go świecie, jaki jest sens i cel jego życia. Wiedzy dającej odpowiedź na te pytania nie są w stanie dostarczyć poszczególne nauki szczegółowe, takie jak: fizyka, biologia, psychologia czy socjologia, ponieważ wiedza ta dotyczy „problemów ogólnoludzkich", które stają przed każdym człowiekiem, niezależnie od epoki, a których postęp nauki nie jest w stanie rozwiązać. Do najważniejszych pytań egzystencjalnych człowieka można zaliczyć następujące:

a) czym jest świat, czy obok bytów materialnych możliwe jest istnienie bytów materialno-duchowych i duchowych;

b) kim jest człowiek, po co żyje i jaki to jego życie ma sens, czy istnieje tylko w wymiarach przestrzenno-czasowych, czy będzie istniał również po śmierci biologicznej;

c) czy istnieje Bóg i jaki to ma wpływ na życie człowieka.

Są to problemy, które od dawna podejmowała, i podejmuje nadal, filozofia. Istnieją jednak zagadnienia, takie jak śmierć czy cierpienie, wobec których nawet filozofia staje się bezradna, natrafia bowiem na granice, których człowiek przy pomocy swego rozumu nie jest $w$ stanie pokonać. Te problemy potrafi pokonać jedynie religia. W świetle religii można odczytać pełniejszą prawdę o człowieku, ukazuje ona bowiem wymiary, które są zakryte dla poszczególnych nauk szczegółowych. Religia dostarcza również duchowych pomocy do pełnego rozwoju człowieka. Każda religia uzupełnia prawdę o człowieku nie negując tej prawdy, którą człowiek może poznać za pomocą własnego rozumu. Dzięki religii ubogaca się światopogląd człowieka ${ }^{36}$, a jego życie nabiera głębszego sensu ${ }^{37}$.

Poprzez religię człowiek dostrzega w Bogu źródło i sens istnienia. Dlatego kontakt $\mathrm{z}$ Nim i zaakceptowanie jego istnienia jawi się jako swoistego rodzaju potrzeba. Z powodu tej potrzeby, człowiek przyjmuje najczęściej znaną od dzieciństwa religię, przyjętą $w$ najbliższym otoczeniu. Jednak nawet taka religia, znana od dzieciństwa i ugruntowana w świadomości, wymaga często pewnej weryfikacji, ponieważ musi ona sprostać nowym potrzebom religijnym, powstającym wraz z rozwojem człowieka. Jeżeli człowiek nie podejmie trudu przeprowadzenia tej weryfikacji, wówczas jego religia będzie miała charakter prymitywny i nie będzie spełniała swoich zadań ${ }^{38}$.

36 Zob. M. RusEcKI, Ku pojęciu światopoglądu, [w:] Z zagadnień światopoglądu chrześcijańskiego (red. M. Rusecki), Lublin 1989, s. 33.: „Swiatopogląd jest zreflektowanym i w pewien sposób uzasadnionym, mniej lub więcej, usystematyzowanym, ogólnym pojmowaniem całej rzeczywistości w aspekcie jej początku, sensu i celu umożliwiającym człowiekowi samookreślenie się w świecie, wobec świata i społeczeństwa, historii i całych dziejów w świetle najwyższych wartości oraz dążenie do ich osiągnięcia, co oznacza możliwość spełnienia się i zrealizowania pełnego człowieka jako osoby zgodnie z jej podstawowymi bytowymi zapotrzebowaniami i egzystencjalnymi dążeniami."

37 Por. Z.J. ZDYBICKA, Swiatopoglądowe wartości religii, tamże, s. 137-148.

38 Zob. E. SUJAK, Rozważania o ludzkim rozwoju, Kraków 1987, s. 236-237.: „Religia prymitywna to religia, której prawdy przekazane w dzieciństwie przyjęło się jako oczywiste, nigdy nie kwe- 
Podstawowym założeniem każdej religii jest więc uznanie Boga jako rzeczywistości nadprzyrodzonej. Szukając początków religii w takich kultach jak animizm czy fetyszyzm, dostrzega się w nich wielką niedoskonałość i ułomność idei bóstwa ${ }^{39}$. Człowiek pierwotny pojmował świat w sposób podobny dziecku. Tak jak dziecko przenosi swoje uczucia na rzeczy martwe, ożywiając je swoją wyobraźnią, tak samo w oczach ludów pierwotnych wszystko żyje i ma jakiś wpływ na egzystencję człowieka. Dlatego człowiek pierwotny przypisywał cechy bóstwa każdej rzeczy, widząc w niej potężniejszą od siebie istotę, która w ten sposób stawała się przedmiotem jego czci. W religiach takich nie ma jakiejś konkretnej idei bóstwa, można zauważyć jedynie świadomość wyższej mocy, innej od sił przyrody. Ta świadomość zależności od bóstwa jest rdzeniem każdej religii. Odczuwając swoją zależność od bóstwa, człowiek stwierdza, że to bóstwo nie jest mu „obce”. Stąd uświadamia sobie, że jego szczęście, los i charakter życia spoczywa w ręku bóstwa, które jawi się jako źródło sensu, z którym całe istnienie człowieka jest ściśle związane i w którym najpelniej realizuje się jego człowieczeństwo ${ }^{40}$.

Istota ludzka często określana jest mianem homo religiosus. $\mathrm{Z}$ tego względu można mówić o „konieczności” religii, oczywiście nie w sensie fizycznym, ale moralnym. Na przestrzeni wieków wypracowano wiele teorii odnoszących się do tego faktu. Przykładowo ateizm zaprzecza istnieniu Boga i neguje konieczność religii, panteizm przeczy osobowej naturze Boga, agnostycyzm neguje możliwość poznania Boga, a materializm zaprzecza istnieniu Boga z powodu niemożliwości istnienia bytów niematerialnych. Istnieją jednak teorie głoszące „konieczność" religii, które opierają swoje postulaty na argumentach z zakresu historii, psy-

stionowane, lecz które pozostały na tym samym co w dzieciństwie poziomie, nie towarzysząc człowiekowi w jego rozwoju. Religia ta, zapełniająca luki w rozumieniu świata i jego praw, nieomal gwarantuje człowiekowi zaspokojenie wszystkich jego potrzeb w zamian za spełnienie stawianych przez nią wymagań. Wszechmocny Bóg stanowi w niej Nadrzędną Instancję wobec świata i na prośbę człowieka, który stara się „być w porządku” wobec Jego przykazań, wkracza w wydarzenia, by zapewnić zaspokojenie ludzkich potrzeb, uwolnić od lęku i zaspokoić pragnienie sprawiedliwości i bezpieczeństwa aż po śmierć. (...) Kiedy jednak życie ukazuje, że nie zabezpiecza On przed cierpieniem, że pozostaje często milczący wobec wołania i kiedy narasta poczucie, że nie sposób uchronić się od winy, a codzienne doświadczenie uczy, że człowiek musi sam sobie radzić ze wszystkim, okazuje się nagle, że można Go unicestwić dla siebie prostą odmową wiary- przecież jest nieoczywisty w swym istnieniu i działaniu. W ten sposób jakże wielu ludzi po prostu wyrasta z religii swego dzieciństwa i rodzinnego domu jak ze złudzeń dziecięcych, które nie wytrzymują zderzenia z rzeczywistością."

39 Por. L. KaczmareK, dz. cyt., s. 199-213.: Animizm (od łac. animus= duch - anima= dusza) teoria, której twórcą był E.B. Tylor. Według niej istotą religii jest dusza, której posiadanie człowiek pierwotny przypisywał wszystkim bytom w naturze, nawet martwym. Wiara w duchy jest niezbędnym warunkiem do zaistnienia religii. Fetyszyzm natomiast jest kultem przedmiotów martwych powstałym w wyniku przypisywania im nadnaturalnych cech, z czym łączyło się oczekiwanie od nich określonego działania w interesie człowieka.

40 Tamże, s. 68-72. 
chologii czy metafizyki. Religia jest zjawiskiem powszechnym, stwierdzonym na podstawie badań historycznych. Psychologiczna konieczność tego zjawiska przejawia się w tym, że stanowi ono zaspokojenie wewnętrznej potrzeby szczęścia u człowieka. Religia zaspakaja również najgłębsze aspiracje i tęsknoty człowieka za prawdą, której nie sposób za życia ziemskiego w pełni osiągnąć, a która ma fundamentalne znaczenie przy poszukiwaniu sensu życia ${ }^{41}$.

Religia broni przed poczuciem bezsensowności i absurdalności życia, przed niepokojami i lękami nękającymi człowieka, stwarza poczucie bezpieczeństwa, staje się „wyznacznikiem” kierunku wszelkich dążeń i działalności ludzkiej. W rozwiązywaniu wszelkich problemów związanych z osobową i międzyosobową egzystencją człowieka, religia sięga do rzeczywistości nadprzyrodzonej.

W obecnych czasach, w których następują gwałtowne przemiany społeczno-kulturalne i ekonomiczno-techniczne, u wielu ludzi religijność zostaje zakwestionowana, jako nie mieszcząca się w ramach współczesnej kultury. W społeczeństwach wysoko rozwiniętych ekonomicznie wyraźnie zarysowują się procesy zmniejszania oddziaływania religii na sferę nadawania sensu ludzkiemu życiu. Jednak ludziom wierzącym religia nadal daje odpowiedź na pytanie o sens życia, umożliwia głębsze widzenie rzeczywistości i stanowi duchową zasadę nadającą pewien porządek bytowi ludzkiemu.

Należy jednak podkreślić fakt, że ludzie niewierzący, którzy odrzucają wszelkie formy i przejawy religijności, potrafią także żyć owocnie i szczęśliwie, potrafią wychodzić „poza siebie" w służbie drugiemu człowiekowi lub pewnym ideom. Oni także poszukują sensu życia, ale obszar swoich poszukiwań zawężają do humanistycznej perspektywy światopoglądowej, zorientowanej na rzeczywistość pozbawioną pierwiastka nadprzyrodzonego. Jednak odrzucenie istnienia Boga rodzi trudność znalezienia celu i kierunku życia pojmowanego w sensie globalnym jako pewnej całości oraz nadania sensu rzeczywistości otaczającej człowieka ${ }^{42}$.

\section{Zakończenie}

Znalezienie sensu swego życia ma fundamentalne znaczenie dla osiągnięcia pełnej dojrzałości i rozwoju osoby ludzkiej, ponieważ wyraża ono przeświadczenie, że istnieje pozytywna odpowiedź na podstawowe pytania człowieka: czy życie ma jakiś cel, czy warto żyć pomimo spotykanych codziennie nieszczęść i niesprawiedliwości. Pogląd przeciwny temu mówi, iż życie jest absurdalne, ponieważ nie można mu nadać jakiegoś konkretnego celu. Poczucie sensu życia jest niezbędne człowiekowi do „pełnego" istnienia. W przeciwnym razie człowiek gubi wszelkie motywy swojego bytu i popada w pustkę egzystencjalną.

41 Tamże, s.77-79.

42 Por. J. Mariański, W poszukiwaniu sensu życia, dz. cyt., s. 62-67; J. PAŁYga, Sens żcia, Communio, 16 (1996) nr 3 (93), ss. 40-46. 


\title{
A Question of the Sense of Life
}

\begin{abstract}
SUMMARY
Nowadays more often people are asking about the meaning of life. It is a fundamental question which every human being faces. Man is asking whether the life is worth of living, what to do to make our life meaningful?

Human being, among many needs, has the need for discovering the sense of life. The need comes from the very core of human existence as placed in time and connected with the phenomenon of passing away. Discovering the sense of life leads to experience of happiness, joy and to inner life lived much more to the full. Showing the meaning of life and helping to find that meaning are very important functions of religion. Due to it a man is able to live one's life, ambitions, goals, joyful moments as well as his or her suffering in the light of deeper understanding. Religion is the one that can often bring the richest and deepest answers to the question of the two meanings: the meaning of life and the world.
\end{abstract}

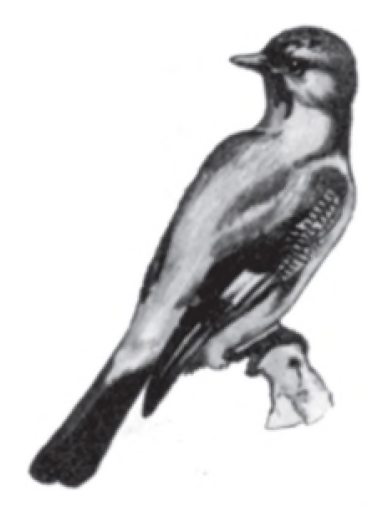

Sójka 